\title{
Assessment of the influence of foliar treatment on productivity and phenolic maturity of grapes
}

\author{
Svetlana Levchenko ${ }^{1}$, Sofia Cherviak $^{1, *}$, Vladimir Boyko ${ }^{1}$, Dmitriy Belash ${ }^{1}$, Elena \\ Ostroukhova, and Natalia Lutkova ${ }^{1}$ \\ ${ }^{1}$ All-Russian National Research Institute of Viniculture and Winemaking "Magarach" of RAS, Kirova \\ Str, 31, Yalta, 298600, Republic of Crimea, Russian Federation
}

\begin{abstract}
An urgent task of today for grape growers is to find effective ways to achieve the compliance of conditional parameters to phenolic ripeness of grapes while maintaining high cropping capacity. In this study the influence of foliar treatment of grapes with nitrogen-containing preparations "Siamino Pro 500" on productivity and phenolic maturity of 'Cabernet-Sauvignon' grape variety was investigated. Studies were carried out during 2018-2019. Grape maturity degree was assessed by the Glories method, based on the determining of the total and extractable anthocyanin potential of grapes. It was shown that, as a result of the experimental scheme of processing, the cropping capacity increased by $10-14 \%$, as well as the bunch weight - by $13-16 \%$. Use of the preparation contributed to the onset of technical maturity of grapes at the earlier period compared to the control. The content of anthocyanins extracted from the skins was 49$56 \%$. Experimental grape samples were characterized by a higher content of titratable acids (by 1.4 and $1.2 \mathrm{~g} / \mathrm{l}$ ) and a lower sugar accumulation (by 9 and $16 \mathrm{~g} / \mathrm{l})$. Positive influence of the experimental scheme of processing on organoleptic properties of wines was observed.
\end{abstract}

\section{Introduction}

The basis of the quality of wine is established at the stage of grape ripening and is formed under the influence of physiological and biochemical characteristics of the variety, soil and climatic conditions of growth and technological methods of cultivation $[1,2,3,4,5]$. For high quality wine production, it is necessary to provide the processing of grapes with optimal conditions: balanced correlation between the content of acids and sugars (potential alcohol), as well as the components of the phenolic complex - extractable substances responsible for the formation of color, aromatic complex and structure of potential wine. One of the criteria for assessing the quality of red wine grape varieties and determining optimal terms of its processing is the phenolic maturity indicator, characterized by the ripening period of grape seeds, as well as a high degree of phenolic substances transfer from the skin of the berry to the must [6]. Quite often, the phenolic ripeness of grapes occurs after reaching optimal conditions for the production of table wines, as a result of which the quality of the finished product decreases, showing excessive astringency and

* Corresponding author: Sofi4@list.ru 
roughness of flavor. Thus, for today an urgent task for winegrowers is to find effective ways to achieve compliance of the conditional indicators with phenolic maturity of grapes. Agrotechnical approaches of influencing the phenolic substances of grapes on biosynthesis include the planting scheme, pruning length, yield regulation, defoliation, as well as irrigation and fertilization $[6,7,8,9,10]$. Positive effect of foliar treatment of grapes with nitrogen-containing preparations on the time of reaching phenolic maturity was found [6]. At the same time, an increase in the cropping capacity due to the use of fertilizers quite often leads to a decrease in the content of phenolic substances in the grape berry, which can negatively affect the quality of the finished product, since the amount of useful components should be evenly distributed throughout the entire crop yield, and a decrease in their content ensures the production of wine with poor aroma and flavor characteristics.

The aim of the research was to assess the productivity and phenolic maturity of grapes on the background of foliar treatment with a preparation based on a complex of amino acids.

\section{Materials and methods}

The object of research is the formation of productivity and phenolic maturity of 'CabernetSauvignon' grape variety.

Single foliar treatment with a preparation based on a complex of amino acids $(600 \mathrm{~g} / \mathrm{l})$ "Siamino Pro 500" ("Biochefarm", Switzerland) at the rate of $1 \mathrm{~kg} / \mathrm{ha}$ was carried out on the experimental plot. System of agricultural actions adopted in the farming served as a control. Experimental studies were carried out during 2018-2019 on 'Cabernet-Sauvignon' grape variety, cultivated in mountain-valley zone of viticulture of the Republic of Crimea in industrial-agrarian association "Massandra", (v. Morskoye, plot No. 202), and in the department of storage and processing of grapes, fruit and vegetable products of the Institute Magarach. The studies were provided in four replicates in each variant of the experiment.

Generally accepted in viticulture methods were used during the research [11]. Planting scheme was $3 \times 1.5 \mathrm{~m}$. Bushes shape was a cordon on a middle trunk. Vertical shoot positioned trellising system was used.

The yield was counted by weighing and counting grape bunches collected from 20 typical bushes of each variant. The average bunch weight was determined by dividing the yield weight of the accounting bushes by the number of bunches collected from these bushes. Estimated weight of the yield per bush and per hectare $(t / h a)$ for each variant of the experiment was determined by multiplying the number of bunches on a bush by their average weight.

Technological assessment of grapes was carried out according to the following parameters: mass concentration of sugars, titratable acids, phenolic substances in the must (PS), $\mathrm{pH}$ [11]. The phenolic maturity of grapes was assessed using the Glories method, based on the determining the mass concentration of anthocyanins in the grape berry $\left(\mathrm{A}_{\mathrm{pH} 3,2}\right)$, the potential amount of recoverable anthocyanins in the winemaking conditions $\left(\mathrm{A}_{\mathrm{pH} 1,0}\right)$, the extractivity of anthocyanins (Ea, or the proportion of non-extractable anthocyanins from the grape skin), the proportion of seed tannins (Mp), the percentage of extractable anthocyanins (A) $[3,12,13]$. The method makes it possible to assess the potential of the present proanthocyanidins and anthocyanins, as well as their ability to be extracted from grapes during processing and further technological operations [4, 12, 13]. All measurements were performed in triplicate.

Calculation of parameters of phenolic maturity of grapes was carried out according to formulae [12]: 
Percentage of extractable anthocyanins, $\%$

Anthocyanin extractability or cellular maturity index, $\%$

Total anthocyanin potential, $\mathrm{mg} / \mathrm{l}$

Potential amount of extractable anthocyanins in the conditions of winemaking, $\mathrm{mg} / \mathrm{l}$.

The proportion of seed tannins in the sum of phenolic substances of the must, \%

$$
\begin{aligned}
& A=\frac{A_{p H 3.2}}{A_{p H 1.0}} \cdot 100 \\
& E A=\frac{A_{p H 1.0}-A_{p H 3.2}}{A_{p H 1.0}} \cdot 100 \\
& A_{p H 1.0}=\left(A_{1.0+W}-A_{1.0+N a}\right) \cdot 875 \cdot 2 \\
& A_{p H 3.2}=\left(A_{3.2+W}-A_{3.2+N a}\right) \cdot 875 \cdot 2 \\
& M p=\left(A_{280}-\frac{A_{p H 3.2} \cdot T A R \cdot 10^{-3}}{A_{280}}\right) \cdot 100
\end{aligned}
$$

* $\mathrm{w}$ - distilled water, $\mathrm{Na}$ - sodium bisulphite; 875 - correction coefficient for malvidin-3glucoside, received for different grape varieties; 2 - dilution coefficient; TAR - average ratio between the total content of phenolic substances $\left(\mathrm{A}_{280}\right)$ and anthocyanins $\left(\mathrm{A}_{\mathrm{pH} 3.2}\right)$ in the must. For unification of different grape varieties the value 40 is taken as a constant [7].

Red table wines were prepared using the following scheme: crushing grapes with ridge separation $\rightarrow$ pulp sulfitation at the rate of $100 \mathrm{mg} / \mathrm{l}$ of total sulfur dioxide $\rightarrow$ pulp infusion for 20 hours $\rightarrow$ fermentation at a temperature of $20-24^{\circ} \mathrm{C}$ on ' $47-\mathrm{K}$ ' yeast race from Magarach collection of winemaking microorganisms until the fermentation of $2 / 3$ of sugars $\rightarrow$ pressing of the pulp $\rightarrow$ post-fermentation $\rightarrow$ sulfitation of wine at the rate of $150 \mathrm{mg} / \mathrm{lof}$ total sulfur dioxide. Sensory characteristics of wines were assessed by the method of organoleptic analysis using 10-point scale.

\section{Results and Discussion}

The entries of two-year tests indicated that as a result of the application of foliar dressing "Siamino Pro 500", the yield increased by $10-14 \%$ compared to the control. Positive effect of processing on the indicators of grape quality was established - the average weight of bunch of experimental variants increased by $13-16 \%$ (Table 1 ).

Table 1. Indicators of grapevine cropping capacity

\begin{tabular}{|l|c|c|c|c|c|}
\hline $\begin{array}{c}\text { Title of the } \\
\text { sample }\end{array}$ & $\begin{array}{c}\text { Year of } \\
\text { harvest }\end{array}$ & $\begin{array}{c}\text { Plot size } \\
\text { (ha) }\end{array}$ & Croppage (t) & $\begin{array}{c}\text { Cropping } \\
\text { capacity (t/ha) }\end{array}$ & $\begin{array}{c}\text { Average bunch } \\
\text { weight (g) }\end{array}$ \\
\cline { 1 - 4 } control & \multirow{2}{*}{2018} & 0.79 & 4.68 & 5.92 & 215 \\
\cline { 3 - 6 } & & 0.58 & 3.77 & 6.50 & 245 \\
\hline experiment & - & - & 0.05 & 0.32 & 7,5 \\
\hline HCP 05 & \multirow{2}{*}{2019} & 0.79 & 4.77 & 6.04 & 225 \\
\cline { 1 - 4 } control & 0.58 & 4.00 & 6.89 & 261 \\
\hline experiment & - & - & 0.31 & 0.05 & 8.3 \\
\hline $\mathrm{HCP}_{05}$ & - & - &
\end{tabular}

The results of study of the carbohydrate-acid potential of grapes are presented in Table 2. The data analysis showed that all grape samples corresponded to the stage of technical maturity and the requirements for technical varieties intended for industrial processing. The research results indicate that the experimental scheme of vineyard fertilization provides a higher content of titratable acids (by 1.4 and $1.2 \mathrm{~g} / \mathrm{l}$ ) with less sugar accumulation (by 9 and $16 \mathrm{~g} / \mathrm{l})$. The studied samples did not differ significantly in the content of phenolic substances - difference between the values of indicators of experimental and control samples did not exceed 5\%. At the same time, it should be noted that the increase in the 
cropping capacity did not lead to a decrease in the total content of phenolic substances in experimental variants.

Table 2. Indicators of technical maturity of grapes

\begin{tabular}{|l|c|c|c|c|c|}
\hline \multirow{2}{*}{$\begin{array}{c}\text { Title of the } \\
\text { sample }\end{array}$} & \multirow{2}{*}{$\begin{array}{c}\text { Year of } \\
\text { harvest }\end{array}$} & $\mathbf{p H}$ & \multicolumn{3}{|c|}{ Mass concentration of } \\
\cline { 4 - 6 } & & sugars, g/l & $\begin{array}{c}\text { titratable acids, } \\
\text { g/l }\end{array}$ & $\begin{array}{c}\text { phenolic } \\
\text { substances, } \mathbf{~ m g / l}\end{array}$ \\
\hline control & 2018 & 3.9 & 232 & 4.7 & 4,886 \\
\hline experiment & 2018 & 3.9 & 223 & 6.1 & 5,071 \\
\hline $\mathrm{HCP} 0_{5}$ & - & 0.4 & 3,7 & 0.5 & 11.8 \\
\hline control & 2019 & 3.4 & 255 & 7.3 & 5,130 \\
\hline experiment & 2019 & 3.2 & 239 & 8.5 & 5,364 \\
\hline $\mathrm{HCP}_{05}$ & - & 0.6 & 4.5 & 0.6 & 7.2 \\
\hline
\end{tabular}

$*$ in the table and below average values of the results of three replicates are shown

As a result of study, positive effect of foliar treatment during the vegetation period with a preparation based on a complex of amino acids on the phenolic maturity of grapes was established (Table 3). Experimental processing scheme contributed to an increase in the extractable $\left(\mathrm{A}_{\mathrm{pH} 3.2}\right)$ anthocyanin potential of grapes by 7 and $8 \%$ in 2018 and 2019 , respectively. Even in spite of the lower value of the total anthocyanin potential $\left(A_{\mathrm{pH}} \mathrm{H}\right)$ in the experimental grape samples of the 2019 harvest, share of the extracted anthocyanins was $14 \%$ higher than the control value. Thus, using of the preparation provided a high degree of a coloring agent returned to the must (the proportion of anthocyanins extracted from the skin was within $49-56 \%$ ). In addition, it is necessary to note the low degree of enrichment with seed tannins in the studied grape samples (less than 60\%) - the value of the indicator, regardless of the variant of experiment, varied in the range of $4.8-8.8 \%$, indicating the high degree of grape ripeness.

Table 3. Indicators of phenolic maturity of grapes

\begin{tabular}{|l|c|c|c|c|}
\hline \multirow{2}{*}{ Indicator } & \multicolumn{2}{|c|}{$\mathbf{2 0 1 8}$} & \multicolumn{2}{c|}{$\mathbf{2 0 1 9}$} \\
\cline { 2 - 5 } & control & experiment & control & experiment \\
\hline $\mathrm{A}_{\mathrm{pH} 1.0, \mathrm{mg} / 1}$ & 743 & 881 & 1243 & 1099 \\
\hline $\mathrm{A}_{\mathrm{pH} 3.2, \mathrm{mg} / 1}$ & 421 & 452 & 520 & 620 \\
\hline $\mathrm{A}, \%$ & 57 & 51 & 58 & 44 \\
\hline $\mathrm{EA}, \%$ & 43 & 49 & 42 & 56 \\
\hline $\mathrm{Mp}, \%$ & 7,3 & 8,8 & 4,8 & 6,1 \\
\hline
\end{tabular}

Thus, the experimental processing scheme contributed to earlier reaching of phenolic maturity of grapes: high percentage of extraction of anthocyanins from the skin, low enrichment of the must with seed tannins.

Organoleptic evaluation of produced wines showed that the experimental scheme of grape processing contributed to the formation of wines with more harmonious aroma and flavor, reflected in a higher tasting assessment (TA) (Table 4).

Table 4. Organoleptic evaluation of wine

\begin{tabular}{|c|c|c|c|c|}
\hline \multirow{2}{*}{$\begin{array}{l}\text { Title of the } \\
\text { sample }\end{array}$} & \multicolumn{3}{|c|}{ Characteristics } & \multirow{2}{*}{ TA } \\
\hline & color & aroma & flavor & \\
\hline control & $\begin{array}{l}\text { ruby, intense, } \\
\text { bright }\end{array}$ & $\begin{array}{l}\text { dimmed, spicy-woody } \\
\text { direction, with light } \\
\text { berry hints }\end{array}$ & $\begin{array}{c}\text { tannin, spicy-berry } \\
\text { direction; } \\
\text { poorly expressed varietal } \\
\text { features }\end{array}$ & 7,7 \\
\hline experiment & $\begin{array}{l}\text { ruby, intense, } \\
\text { bright }\end{array}$ & $\begin{array}{l}\text { berry direction with } \\
\text { light spicy and creamy } \\
\text { notes }\end{array}$ & $\begin{array}{l}\text { smooth, berry direction, } \\
\text { harmonious; well- } \\
\text { expressed varietal features }\end{array}$ & 7,8 \\
\hline
\end{tabular}




\section{Conclusion}

Thus, according to the results of two-year studies of the influence of foliar treatment with preparation "Siamino Pro 500" based on amino acids, a positive effect on the time of reaching the phenolic maturity of grapes was established. Using of the preparation contributed to the reaching of technical maturity of grapes at an earlier date compared to the control. Share of anthocyanins extracted from skins was $49-56 \%$, as well as a low degree of enrichment with seed tannins. Experimental grape samples were characterized by a higher content of titratable acids (by 1.4 and $1.2 \mathrm{~g} / \mathrm{l}$ ) and a lower sugar accumulation (by 9 and 16 $\mathrm{g} / \mathrm{l})$. Positive effect of the experimental processing scheme on the organoleptic properties of wines was observed. It was shown that as a result of the experimental processing scheme, cropping capacity of grapes increased by $10-14 \%$, as well as the bunch weight - by 13 $16 \%$.

\section{References}

1. P.J. Beer Grape and wine phenolic composition as a result of training system and canopy modification in Vitis vinifera L.cv Shiraz. (Stellenbosch University, Stellenbosch, 2015)

2. S.V. Levchenko, E.V. Ostroukhova, I.V. Peskova, P.A. Probeigolova, Productivity of horticultural crops in iran: potentials, production limitations, possible solutions and international collaborations (Tarbiat Modares University, Tehran, 2017)

3. S. Segade, S. Giacosa, V. Gerbi, L. Rolle, Red Wine Technology, 1-16 (Academic Press, 2019)

4. E. Ostroukhova, S. Levchenko, V. Likhovskoi, V. Volynkin, I. Peskova, I. Vasylyk,

1. Acta Horticulturae, 1259, 105-113 (2019)

5. Y. Zhou, P. Su, H. Yin, Z. Dong, L. Yang, C. Yuan, South African Journal of Enology \& Viticulture, 40 (2), 120-131 (2016)

6. S. Villangó, Examination phenolic maturity of Syrah grape variety. Doctoral (PhD) Theses. (Corvinus University of Budapest, Budapest, 2015)

7. S.N. Cherviak, V.A. Boyko, S.V. Levchenko, Horticulture and viticulture, 4, 30 (2019) (in Russian)

8. N. Kontoudakis Grape phenolic maturity; Determination methods and consequences on wine phenolic composition. Ph Doctoral Thesis. (Universitat Rovira i Virgili, Tarragona, 2010)

9. Sz. Villangó, Gy. Pásti, M. Kállay, A. Leskó, I. Balga, A. Donkó, M. Ladányi, Z. Pálfi, Zs. Zsófi, S. Afr. J. Enol. Vitic., 36 (3), 304-315 (2015)

10. E. Stranishevskaya, E. Ostroukhova, I. Peskova, S. Levchenko, E. Matveikina, N. Shadura, E3S Web of Conferences 161, 01070 (2020)

11. Compendium of international methods of wine and must analysis. Paris. (2017)

12. H.N. Rajha, N.E. Darra, S.E. Kantar, Z. Hobaika, N. Louka, R.G. Maroun, Antioxidants, 6, 1 (2017)

13. A.P. Nel, S. Afr. J. Enol. Vitic., 39(1), 1-20 (2018) 